was a button-like nodule of hard carcinomatous growth, invading the adjacent part of the tumour, but not penetrating deeply into it. Dr. H. D. Rolleston kindly exumined it microscopically. He found the nodule of recent growth to be a typical specimen of scirrhous carcinoma. The rest of the tumour remained quite free from carcinoma and showed only the ordinary appearance of a fibro-adenoma, excepting the cystic part, which, besides fibrous tissue of old standing, showed compressed gland tubes and dilated ducts, with a few papillomatous processes projecting into the dilated ducts.

Here, then, was a case which, during nine years' careful observation, exhibited the clinical features and history of fibro-adenoma, but which then took on the charwcters of active carcinoma. Eleven months after the removal of the breast two small nodules of scirrhus were removed from the neighbourhood of the scar. The patient has since remained well. It seems probable, though of course it cannot be proved, that if the adenoma had been removed when first seen the subsequent cancerous invasion might have been avoided. At any rate I cannot but think that in the light of this and other somewhat similar cases (e.g, that of Mr. J. Hutchinson, jun., in which cancerous growth occurred around an adenoma of long standing ${ }^{1}$ ) we shall be doing what is best for our patients by advising the removal of all adenomata of the breast, even of those which seem quite stationary and quiescent.

Savile-row, W.

\section{COEXISTENCE OF INFECTIOUS DISEASES IN THE SAME INDIVIDUAL.}

By EdWard CaRmichael, M.D., M.R.C.P. EdiN., VISITING MEDICAL OFFICER TO THE CITY POORHOUSE, CRAIGLOCKHART

Is connexion with Dr. Caiger's paper on the above subject at the Epidemiological Society ${ }^{2}$ the following case seems worth putting on record, it being unique so far as my experience goes, but I would gladly hear of any other similar case.

The patient, a boy six years of age, had been ill for four days before I saw him, suffering from sore-throat, vomiting, and a slight rash. I suspected it might prove to be a case of scarlet fever. The boy was still feverish, although no rash was to be seen, and accordingly I looked for desquamation. This soon appeared and confirmed the diagnosis. What puzzled me was the temperature still remaining bigh. Diarrhcea set in, then splenic enlargement, but there were no spots on the abdomen. The enlargement of the spleen became so marked and the anæmia so profound that $I$ began to fear I had to do with an acute case of leucocythæmia. Dr. Cland Muirhead kindly saw the boy in consultation with me, and after examination was inclined to think it might be leucocythæmia, but thought I should still keep typhoid fever in view seeing the microscopic examination of the blood showed no very marked increase of leucocytes. After a prolonged illness the spleen began to diminish, the diarrhoea to cease, and a slow but steady recovery ensued, thus putting leucocythæmia out of the question. The interesting and, as I have said, unique point was that this boy infected his sister, whom we had to keep in the house, with a distinct and typical scarlet fever which set in about ten days after my visits began, and some weeks after the father, while helping to nurse the boy, went through a typical typhoid fever, with the usual temperature curve, rash, and diarrhoea, so that my diagnosis was that the boy had both scarlet fever and typhoid fever, that he gave the one to his sister and the other to his father. All three patients recovered. No defective drainage or water- or milksupply could be traced, but I found that a day or two before the illness began the boy had let a key fall through a grating of the street gutter, to recover which he lifted the grating, lay down and scraped among the débris.

London-street, Edinburgh.

Path. Trans., vol. xxxix., p. 319

2 THE LANCET, May 5th, 1894.
Path. Trans., vol. xxxix., p. 319.

The Duke and Duchess of Fife recently opened the new buildings of the St. Marylebone General Dispensary, Welbeck-street. The buildings have been erected at a cost, inclusive of fittings, of $£ 6000$, some $£ 2000$ of which still remains to be collected in order that the buildings may be entirely free from debt.

\section{A athitror}

OP

\section{H O S P T A L P R A T I CE, BRITISH AND FOREIGN.}

Nulla autem est alia pro certo noscendi via, nisi quamplurimas et mor borum ot dissectionum historias, tum aliorum tum proprias collectas habere, et inter se comparare.-MORGaGNi De Sed. et Caus. Morb., lib. iv. Procemium.

\section{ST. THOMAS'S HOSPITAL.}

MYOMA OF UTERUS -OVARIAN TUMOUR WITH TWISTED PEDICLE.

(Under the care of Mr. WM. ANDERson.)

THE method of operation for uterine fibroid described is the following history of a case recently under the care of Mr. Anderson shows the excellence of this method of treat ment when it can be employed. The contrast between the extra-abdominal treatment of the pedicle and the intra abdominal is very great, and those who have only had an experience of the former will recognise the great advantages which the latter offers. Instead of the continued attention which the extra-abdominal method requires until the separation of the wire, a process not unattended with anxiety, the whole of the after-treatment in the intra-abdominal methoc is limited to that of an ordinary laparotomy.

CASE 1. Myoma of uterus; operation by a moatifieation of Schroeder's method; recovery. - The patient, a married woman thirty-five years of age, was admitted into St. Thomas's Hospital on Dec. 15th, 1893. She had suffered for two years from menorrhagia, at first almost painless, but more recently associated with dragging sensations that greatly interferec with her domestic work. In other respects she had alwass enjoyed good health. It was said that her mother had undergone an operation for an abdominal tumour, but there was no information as to the nature of the growth. On admission the patient, a woman of fairly healthy aspect, was suffering from a tumour in the lower part of the abdomen. The growtb was central and extended from behind the symphysis to within an inch of the umbilicus. It was spherical and smooth, and was connected on each side with a cord-like band, which ran outwards from near the upper end of the tumour towards the pelvic brim. On examination per vaginam the aterine canal was discovered to be about four inches in length and displaced forwards, apparently by a growth in the pos terior wall of the organ. On Jan. 1st, 1894, ether having beer administered, an incision three inches and a half in length was made in the median line of the abdomen, between the symphysis and umbilicus, exposing a tumour which was seen to consist of the enlarged uterus with its appendages. On drawing the mass from the abdominal cavity, after enlarging the incision, the cervix was found free from growth anc forming a distinct pedicle. The ovarian vessels were then ligatured in the infundibulo-pelvic ligaments, the uterine vessels secured on each side of the cervix, and the broad ligaments were divided, leaving the appendages attached to the uterus. The tumour thus freed, an incision was made through the cervix ateri near its junction with the body in such a way as to leave anterior and posterior flaps, and the whole mass was removed. The operation was almost blocdless, only two or three small vessels in the broad ligaments requiring ligature. The cavity of the cervix being recognised on the face of the stump, the edges of the mucous membrane were united by catgut sutures; a second set of buried silk stitches were then passed through the thickness of the cervical walls on each side, uniting the whole of the opposed surfaces of the two flaps ; finally, the peritoneal edges of the flaps and divided broad ligaments were brought together by Lembert sutures. The abdomen was closed by deep and superficial sutures, without drainage. The operation, althougb necessarily long, was well borne. No complication arose except some suppuration in the course of the superficia parietal sutures, which, however, did not interfere with progress to any material extent. The patient was dischargec cured on Jan. 30th.

Remarks by Mr. ANDERson.-The tamour proved to be, as diagnosed, an intra-mural myoma in the posterior wall of the uterus, not encroaching upon the cerrix. The case was cae 